\title{
ENTRE 0 QUADRO E 0 SEPULCRO: Strether, Aires e 0 Cerco aO Real ${ }^{*}$
}

\author{
Marcelo Pen Parreira
}

Universidade de São Paulo

\section{Resumo}

A partir de cena do romance Os embaixadores, de Henry James, e de Memorial de Aires, de Machado de Assis, este artigo procura confrontar as estratégias narrativas dos dois autores com o objetivo de mostrar como ambos, ao trazer à cena a perspectiva do sujeito equívoco e equivocado, não só alargaram as fronteiras da representação do mundo material e social, mas ainda sugeriram um viés mais refletido de consciência estética.

\section{Abstract}

This article attempts to approach the strategies put to use by Henry James and Machado de Assis, particularly in two scenes from their novels The Ambassadors and Memorial de Aires. Our objective is to show how the two of them, as they bring forth deceived and deceiving characters, not only broaden the realms of representing material and social world, but also suggest a Palavras-chave Henry James; Machado de

Assis;

Realismo;

Representação;

Consciência.

\section{Keywords}

Henry James; Machado de Assis; Realism; Representation; Awareness.

* Este texto é uma versão modificada de um capítulo do livro Realidade possível: dilemas da ficção em Henry James e Machado de Assis (no prelo), obra que, por sua vez, é uma nova versão de minha tese de doutoramento. O capítulo mencionado, entretanto, não se encontra na tese. 


\begin{abstract}
"In another moment Alice was through the glass, and had jumped lightly down into the Looking-glass room. The very first thing she did was to look whether there was a fire in the fireplace, and she was quite pleased to find that there was a real one, and blazing away as brightly as the one she had left behind."

(Lewis Carroll, Through the Looking-Glass)

"O matagal não é o bosque sagrado."

(Theodor Adorno, Minima moralia)
\end{abstract}

\title{
P
}

ara entendermos melhor a modalidade de realismo engenhada nas obras maduras de Henry James e, assim, percebermos como ela se diferencia da praticada por Balzac ou Flaubert, por exemplo, e sobretudo das páginas da ficção inicial do autor (em que se percebe uma tônica mais próxima aos realistas europeus), precisamos deter-nos alguns instantes num episódio bastante estudado de Os embaixadores, ou seja, o da jornada campestre de Strether, ao cabo da qual também acaba descobrindo o embuste armado por Chad e Madame de Vionnet.

Menos do que examinarmos o "flagrante" em si, bem como suas consequências, interessa-nos entender como James introduz o quadro da natureza nessa cena, a realidade observada - uma estratégia da qual até mesmo o momento climático da cena parece derivar. Alguns dias após uma conversa com Miss Gostrey, Strether toma o trem para uma estação do interior, "selecionada quase a esmo". Embora o acaso pareça desempenhar, portanto, um papel de destaque no evento, somos obrigados a admitir logo de início, se estivermos bem atentos, que a lógica da cena não se dá pelo sabor da sorte, mas é regulada por outro elemento igualmente vasto, malgrado suas implicações menos fortuitas: a memória. ${ }^{1}$

Pois a verdade é que o quadro do "ruralismo francês" em que Strether mergulha é, em primeira instância, um quadro de fato, uma tela que ele antes só havia observado "pelo vidro oblongo de uma moldura". Trata-se de um "pequeno Lambinet" que o herói viu em uma galeria de Boston e, mais do que ver, ensaiou comprar e, mesmo diante da impossibilidade da aquisição, ou quem sabe justamente por causa disso, nunca mais o esqueceu. "Durante uma hora", Strether revirou todos os meios de que dispunha, para adquiri-lo. Afinal, como o informaram, o quadro estava sendo negociado pelo valor mais baixo jamais oferecido por um

${ }^{1}$ Todas as citações feitas neste capítulo à cena referida estão em Henry James, The ambassadors, Cambridge, The Riverside Press, 1960, p. 318-31, a terceira e a quarta partes do $11^{\circ}$ livro do romance. 
Lambinet - "um preço mediante o qual nunca se sentiu mais pobre por ter de reconhecer, mesmo assim, que estava fora de suas possibilidades". Fora sua única "aventura" de compra de um objeto de arte, o único momento em que talvez tenha sentido que sua vida quase se igualava àquelas a que estava subjugada, isto é, a dos ricos cuja escadaria, conforme pondera ele no fim do romance, a custo era obrigado a galgar. Fora de fato uma aventura modesta, como eram de fato modestos os seus recursos, em comparação; nada obstante, aquele Lambinet constituiu o quadro "que teria comprado - a criação particular que o fez, por um minuto, vencer sua natureza frugal".

A memória, diz o narrador, era doce, mas não poderia vir senão embalada pela consciência da posição que ele exerce nessa história - posição que o faz sofrer tantos equívocos e atribulações na busca ao herdeiro indeciso - sua condição de subordinação, de emissário e representante daquilo que, em essência, ele não é. Strether não só se mostra muito ciente dessa sua condição, como também costuma reduzir as relações interpessoais a essa pequena convenção, conforme comenta Maria Gostrey no diálogo que antecede o passeio: "O modo como o senhor fala das pessoas, como se regidas por uma lei de sujeição!". 2

Seu estado de emissário de forças econômicas e sociais que o ultrapassam e o dominam (dominando-o por serem maiores que ele?) dão às suas reminiscências, por conseguinte, um tom entre suave e melancólico. Strether nunca o esperou rever, esse seu Lambinet, nunca teve esperança de que a "roda do tempo" o trouxesse de volta - tal como o admirara no "espaço marrom-avermelhado, iluminado pela clarabóia, do santuário íntimo da rua Tremont". Mas topar com o quadro de novo era uma coisa; sendo outra bem diferente ver tudo aquilo restituído a seus elementos originais, ou seja, à natureza. Era isso, portanto, o que estava ocorrendo. O espaço do quadro rememorado voltava ao cenário original que Strether tinha enfim a oportunidade de observar. Só que, nessa "restituição", as demais circunstâncias de outrora forçosamente retornam também, misturados de enfiada, como que forçando uma camada de pentimento à paisagem natural: "o dia empoeirado em Boston, os fundos do armazém Fitchburg, o sacrário marrom-avermelhado, a bela imagem em verde, o preço escandaloso, os choupos, os salgueiros, os juncos, o rio, o céu ensolarado e raiado de prata, o horizonte do bosque umbroso". Como expectador, Strether reformulou a obra observada e, agora, diante do universo rural que supostamente a havia inspirado, rearranja-o segundo antigas vicissitudes.

Assim, toda a cena que agora se descortina diante dos olhos do herói vem dirigida por aquele episódio do passado, um episódio que se amplia a ponto de abarcar toda sua existência. A natureza não tem como ser apenas a natureza; isso já não é possível, talvez nunca foi; novos significados se agregaram, e ele não consegue vê-la senão através das lentes da lembrança, do espaço da memória onde se alojam tanto a consciência de suas circunstâncias pessoais quanto a influência de

${ }^{2}$ No original: "The way you reduce people to subjection!". A tradução francesa, de Georges Belmont, busca um sentido ao mesmo tempo mais livre e significativo, mas ainda possível: "Cette façon que vous avez, de réduire les gens en esclavage!". Idem, p. 308; Henry James, Daisy Miller, Les ailes de la colombe, Les ambassadeurs, Paris, Robert Lafont, 1999, p. 804. 
outros olhares. Pois o campo de Strether é um campo regido pela "fantasia", pela "ficção" elaborada pelos escritores que ele leu, pelos artistas que admirou. Assim como Victor Hugo move a cognição de Strether pelas ruas de Paris, assim como o Mürger das Cenas da vida boêmia condicionou suas primeiras expectativas acerca de Chad, o Lambinet conduz seu olhar durante toda a cena no campo.

Todos e cada um dos elementos apresentados são romanescos, pictóricos, livrescos, convencionais. Os "choupos e os salgueiros, os juncos e o rio - um rio cujo nome não sabia, nem pretendia saber"; o céu "todo prateado e turquesa e verniz"; a aldeia à esquerda "toda branca e a igreja à direita, cinzenta". Tudo era real porque tudo era fantasia. Ali ele estava em meio à natureza, enquanto seu compromisso continuava a limitar-se "a antiquadas idiossincrasias bostonianas". A moldura dourada continua a cercar o mundo natural para ele; e o campo, o panorama rural "era o que ele queria: era a rua Tremont, era a França, era o seu Lambinet".

Para Strether, Émile Lambinet (1813-1877), como outros artistas dotados de um viés menos realista, calam fundo no coração, soprando como que uma névoa fina sobre seu espírito imaginativo. A arte de uma era mais antiga, ao mesmo tempo clássica e romântica, de uma perspectiva ao mesmo tempo cândida e idealista, ${ }^{3}$ com tudo o que ela possa ter de subjetivo e de artificioso, de belo e de fascinante, apresenta-lhe um quadro da realidade que ele não tem mais como ver de forma inteiramente objetiva.

Mas a imaginação de Strether não se pauta apenas por artistas de identidade romântica ou idealista - Maupassant é trazido à cena quando se descrevem os aldeões que ele imagina encontrar. Vale a pena destacar o trecho:

Havia um trem de volta a Paris às nove e vinte, e Strether já se via provando, ao término da jornada, de algum tipo magnífico de fritura acompanhada por um vinho autêntico, realçados por uma rústica toalha de mesa branca e por um belo piso polido; depois disso, podia, se quisesse, caminhar indolente ao crepúsculo até a estação, ou então optar pela carriole local e conversar com o cocheiro, um cocheiro de fala expansiva que naturalmente só podia estar usando um gorro de tricô e uma túnica rija e asseada - um cocheiro que, em suma, sentado na boléia, contar-lhe-ia o que pensavam os franceses e que o faria lembrar-se, como na realidade todo o episódio incidentalmente faria, de Maupassant. Strether ouviu brotar de seus lábios pela primeira vez em solo francês, à medida que a cena adquiria consistência, palavras que expressavam sem pejo o seu propósito.

À exceção do comboio noturno de regresso a Paris, que o levaria à capital na hora prevista (uma inferência, portanto), toda a cena deriva da imaginação de Strether. Em sua mente, quando o episódio assim se reproduzisse - pois para ele só assim poderia reproduzir-se -, seria como se saltasse de uma página do escritor francês, pois era a página do escritor francês que ele já estava vivendo. Mas, à medida que o herói se punha a cismar, a cena para ele também se tornava mais real,

\footnotetext{
3 "Para nosso amigo, aquela ainda era, em grande medida, uma terra de fantasia - o pano de fundo da ficção, a ambientação da arte, o berçário das letras; praticamente tão distante quanto a Grécia, mas quase tão consagrada. Aos olhos de Strether as histórias românticas pareciam tecer-se a partir de elementos igualmente suaves...".
} 
e Strether podia ouvir, não, Strether deveras "ouviu" (pois o narrador emprega o tempo no passado do indicativo e não num modo condicional) seus lábios responderem aos aldeões sem o temor que sentia quando falava com Chad, com Madame de Vionnet ou com Waymarsh. Maupassant trouxe-lhe as figuras com quem ele teve a confiança de falar. O seu futuro (projetado) já era o seu passado (imaginado).

Embora Strether se perca novamente em seu Lambinet e embora ele adormeça, os sentidos entorpecidos, a menção a Maupassant, o Maupassant realista das cenas da vida campesina, mostra que a imaginação do personagem não se pauta por conceitos de uma única ordem (como as leituras românticas de Madame Bovary), mas de várias, todas capazes de determinar a realidade por meio do grão sugestivo. A ideia é que Strether está no quadro da ficção, na tela da representação (alheia, assim, a escolas ou disputas acadêmicas) e aí permanece durante "todo o resto do dia daquele dia vagabundo". A moldura se afasta para ele, ampliando o escopo do mundo retratado, de modo que ele não a ultrapassa sequer uma vez. Não a ultrapassa quando avista a aldeia "que se lhe apresentou como algo torto, feito de branco e azul"; quando degusta uma bock suave, quando para aquela aldeia enfim se dirige e no albergue Cheval Blanc pede uma "côtelette de veau à l'oseille" - e, mesmo distante de tudo e de todos, nunca se sentiu mais envolvido com os demais e situado "bem no centro de seu drama".

Os detalhes realistas realmente abundam agora, da rústica estalajadeira ao nome do prato pedido, mas o fato é que eles foram introduzidos em consonância com a menção a Maupassant; ou seja, mesmo os dados realistas aqui elencados parecem provir da imaginação de Strether, que se pauta por suas leituras - e não é à toa que, depois de falar de quadros e livros, enfim se estabeleça uma metáfora com o drama. As pessoas tornam-se personagens dramáticas e o mundo, um palco. E que palco melhor, mais distante da realidade de Woollett - mais distante até que o salão de Madame de Vionnet, com "os fantasmas do Império" - que o pequeno pátio do Cheval Blanc, situado na aldeia que lhe chamou a atenção, quando a viu do alto, pelos tons de branco e azul, e por seu padrão tortuoso ("a thing of whiteness, blueness and crookedness"; "crooked" podendo indicar tanto algo visualmente torto quanto implicitamente desonesto; ou seja, uma trapaça).

Strether sente uma espécie de inevitabilidade, de que havia providenciado com a estalajadeira - essa figura também como que sacada de Maupassant - para que naquele momento chegasse ao "clímax", outra palavra com repercussões dramáticas. As condições ali representavam então, justamente, "the thing" - a coisa em si, o cerne da questão. É nesse ponto climático que ele intui que todas as observações até então feitas se ajustam e que "não houve um único sopro da fresca brisa noturna que não constituísse de algum modo uma sílaba do texto".

"Era estranho (queer), sem dúvida", imagina Strether e, para nós, soa ainda mais interessante o fato de que, em meio a esse mergulho tão intenso na natureza, mas numa natureza tão projetada, tão fabricada e feita de uma miríade de rearranjos internos, tanto artísticos quanto sociais, que essa natureza enfim constituísse uma "sílaba" de um texto que ali estava sendo escrito. A menção lembra, inclusive, o depoimento de caráter bem mais fantástico da preceptora de A volta do parafuso, que, para atestar a nitidez da primeira aparição de Peter Quint, diz: "eu o vi 
como vejo as letras que formo nesta página". É preciso que entendamos bem a inversão que ocorre no caso de Strether, uma inversão que parece inverter a hipótese examinada por Adorno e Horkheimer, de quando a palavra, por causa da separação entre ciência e poesia, perde sua conexão com a natureza: "Enquanto signo, a linguagem deve resignar-se ao cálculo; para conhecer a natureza, deve renunciar à pretensão de ser semelhante a ela. Enquanto imagem, deve resignar-se à cópia; para ser totalmente natureza, deve renunciar à pretensão de conhecê-la". ${ }^{4}$

Ora, na passagem de James a palavra não se preocupa com a impossibilidade de conhecer a natureza, pois é a própria natureza que se torna verbo, se torna texto. Gera-se uma nova igualdade nesse contexto, mas por uma via invertida, estéril e estetizante talvez, mas ainda assim assumindo foros de uma nova genealogia (ou, nas circunstâncias, de uma escatologia?): brisa-sopro, palavra-verbo. Cópia da cópia, espelho do espelho, a natureza vira um simulacro que fornece objetos semelhantes ao da ficção: belos, falsos, a um só tempo desconhecidos e familiares.

O texto era de Strether, por certo, mas o texto era também de um autor debruçado sobre seus ombros. Cremos que em nenhum momento no romance, mesmo aqueles nos quais o autor se apresenta por meio da primeira pessoa do plural ou mesmo do singular, mesmo quando se refere a Strether como "nosso amigo", mesmo quando faz algum tipo de comentário irônico acerca da situação, em nenhuma dessas instâncias sentimos tão de perto os "toques que ultrapassam qualquer sensação" a que se refere Lubbock, indicando que "alguém está olhando por cima de seus ombros - vendo coisas do mesmo ângulo, mas vendo mais". ${ }^{5}$

Aqui talvez seria o momento em que a "retórica da dissimulação" de que fala Booth (necessária para que a ilusão da realidade tenha maior eficiência, mesmo sob o perigo de falsificar a vida $)^{6}$ atinge seu grau máximo - a não ser que argumentemos, é claro, que ela também alcança seu grau mínimo, no sentido em que percebemos na alusão, nesse trecho como que esgarçado do tecido narrativo, toda uma série de consequências que excede o quadro objetivo retratado; no sentido que não só intuímos com muita clareza o olhar do autor implícito ou inferido, como ainda deparamos com a ideia do próprio texto que infere esse autor. ${ }^{7}$ Sem

${ }^{4}$ Theodor W. Adorno e Max Horkheimer, A dialética do esclarecimento: fragmentos filosóficos, Rio de Janeiro, Jorge Zahar Editor, 1985, p. 31; Henry James, "A volta do parafuso", in Contos de horror do século XIX, São Paulo, Cia. das Letras, 2005, p. 152.

${ }^{5}$ Percy Lubbock, The craft of fiction, New York, The Viking Press, 1976, p. 258-61. Em seu artigo sobre o primeiro parágrafo de Os embaixadores, Ian Watt também aponta para a qualidade multidimensional da narrativa, em que entra em jogo não apenas o olhar do personagem, mas também de um autor implicado, além da visão do leitor: "Um motivo para a prosa ficcional de James exigir tanto de nossa atenção é certamente o fato de haver sempre pelo menos três tipos de desenvolvimento - todos subjetivos; a consciência dos personagens sobre os eventos, a visão do narrador sobre eles e, a reboque, nossa própria percepção sobre essas duas instâncias. [Ian Watt, "The first paragraph of The ambassadors", in Ruth Bernard Yeazell, Henry James: A collection of critical essays, New Jersey, Prentice Hall, 1994, p. 124.

${ }^{6}$ Wayne C. Booth, The rhetoric of fiction, Chicago, The University of Chicago Press, 1979, p. $42-4$.

${ }^{7}$ Booth diz que quando o autor escreve, não "cria simplesmente um 'homem genérico' ideal ou impessoal, mas uma versão implícita 'de si mesmo', diferente do autor implícito que encontramos na 
prejuízo à dissimulação, porém, James não expõe a farsa narrativa, o compromisso com a ilusão; a farsa, para ele, será outra, como veremos. Assim como a moldura retrocede até o limite para que Strether caminhe pelo campo sem sair do "santuário íntimo" de suas lembranças da rua Tremont, também James chega ao limite da esgarçadura de sua produção textual, onde podemos entrever o arcabouço retórico, as molas e as engrenagens por baixo da máquina, apenas para ligar o sopro da brisa noturna (um dado da natureza) à sílaba do texto (o dado retórico).

E o que esse texto diz, quando decifrado, é o que qualquer texto diz, ou seja, que as coisas são como são e, se alguém é escolhido "para percorrer a cena", essa pessoa deve "acertar contas com o que deparou". Percorrer a cena ou percorrer o texto (move about, no original); como leitores do grande texto do mundo que no fundo só pode corresponder ao grande texto da arte, temos de assumir responsabilidade sobre os nossos achados. E o que Strether achou foram os mecanismos da farsa, que é e não é a farsa do texto, mas será sobretudo o da comédia que ele então estava vivendo. Mas não foi o acaso (ou seja, o grande deus da natureza científica) que acionou os dados; foram os próprios dados que fabricaram o acaso, possibilitando o clímax.

Não é à toa, também, que a estalajadeira com que Strether preparou o seu clímax, agora lhe sugira o "agrément do rio". A palavra, citada em francês, é empregada em português e também em inglês, no sentido de uma aprovação oficial concedida a um diplomata, sendo portanto bastante apropriada quando citada a respeito de um emissário dos interesses da Nova Inglaterra. Em inglês, quando usada no plural, também alude a ornamentos musicais ou circunstâncias ou qualidades agradáveis. De fato estas duas últimas acepções estão mais próximas da ideia original, do agrado ou deleite proporcionado por alguma coisa. No radical está o vocábulo gré, traduzido por grado, vontade ou querer; grado e gré derivando do latim gratus: agradável, digno de gratidão ou reconhecimento.

No fundo, o que se oferece a Strether é essa visão mais agradável do rio - uma visão onde colherá os frutos dourados do clímax a que se acomodara. Trata-se de algo que lhe é concedido, mas também que lhe é deleitoso, que se submete a seu grado ou vontade. E já se disse pouco antes como ele se sente bem à vontade agora para expressar, com a devida ajuda de Maupaussant, seu vocabulário e sua intenção. Trata-se de uma impressão, portanto, não destituída de implicações afetivas; ela se acolhe no íntimo do personagem, liga-se à sua disposição interior, como a sílaba à brisa, como o Lambinet à paisagem.

Assim, quando Strether descobre que o jovem senhor e a jovem senhora descendo o rio são ninguém menos do que Chad e Madame de Vionnet, que os dois planejaram uma escapada idílica à sua revelia e, que, ao serem surpreendidos (e antes de saberem que haviam sido reconhecidos), em alguns instantes pensaram em esnobá-lo e, ainda mais, sem alternativas senão admitirem que foram apanhados,

obra de outros homens [...] O 'autor implicado' escolhe, conscientemente ou não, o que lemos; nós o conjeturamos como uma versão criada, literária e ideal, do homem real; ele é a soma de suas próprias escolhas". Cf. W. Booth, The rhetoric of fiction, op. cit., p. 70-5. 
seguem agindo como se nada houvesse acontecido, como se aquele fosse apenas um passeio comum, como se não estivessem romanticamente enlaçados - assim, depois de tudo isso, com a moral da história sendo que tudo só podia ser parte de tudo mais, não podemos deixar de admitir que essa sua descoberta pertencia antes à sua sensibilidade estética, ${ }^{8}$ e que a sensibilidade estética se ligava à sua condição pública e pessoal e que, por fim, essa sua condição estava no fundo relacionada com a aquisição malograda do pequeno Lambinet.

O Lambinet que Strether não pôde ter equivale à consciência que ele só adquire mediante a débâcle de seus ideais. Edel admira-se da ingenuidade do personagem, tão cego àquilo que todos sabiam; ${ }^{9}$ porém, mais evidente ainda é o fato de sua falta de visão, equiparada à sua falta de recursos, não advir da ausência de sensibilidade, muito menos de imaginação ou do embotamento dos sentidos, mas do excesso dessas particularidades, da mistura disso com sua disposição íntima e seu lugar social; da totalidade de seu ser, em suma. Era tão estranho (queer) quanto algo extraído da ficção ou da farsa, cogita Strether, que o campo eleito por Chad e Madame de Vionnet fosse também o campo escolhido por ele, mas a verdade é que só podia ser mesmo um dado ficcional, pois o embuste promovido pelos dois era agora tão real quanto o quadro que só existe como ausência, quanto a aventura de seu fracasso.

Na superfície, contudo, nada disso vem à tona; na superfície só se alude à "invraisemblance geral da ocasião" (mais uma referência dramática). A inverossimilhança é tanto o que de mais absurdo e farsesco há em tudo aquilo quanto o que pode haver de mais autêntico naquela realidade improvável. A falsidade da situação do herói alia-se à falsidade do evento como se esse fosse o desenlace logicamente mais plausível. Strether vive num mundo onde o falso que gera o falso imprime enigmaticamente o gosto da realidade. Como diz Aristóteles, "se um primeiro fato é falso, mas, existindo ele, um segundo tem de existir ou produzir-se necessariamente, cabe acrescentar este, porque, sabendo-o real, nossa mente, iludida, deduz que o primeiro também o é". ${ }^{10}$

A inverossimilhança verossímil da farsa só pode ser revelada mediante uma perspectiva profunda, que não existe mais, pois esbarra na superficialidade da tela ou das relações submetidas à nova escravatura da era moderna pós-colonial. A estranheza se instala, bem como o fracasso de toda longa cadeia de delegados (fracasso

\footnotetext{
${ }^{8}$ Ideia reforçada pela descrição do jovem, "o herói sem casaca daquele idílio". Sobre a relação do nosso conhecimento com a sensibilidade estética, diz Nietzsche em O nascimento da tragédia que os seres humanos somos "imagens e projeções artísticas, e que nossa suprema dignidade temo-la no nosso significado de obras de arte - pois só como fenômeno estético podem a existência e o mundo justificar-se eternamente -, enquanto sem dúvida, a nossa consciência a respeito dessa nossa significação mal se distingue da consciência que têm, quanto à batalha representada, os guerreiros pintados numa tela". Cf. Friedrich Nietzsche, O nascimento da tragédia, São Paulo, Companhia de Bolso, 2007, p. 44.

${ }^{9}$ Leon Edel, "Introduction", in The ambassadors, London, The Bodley Head, 1980, p. 9; e, na verdade, Strether imagina Miss Gostrey perguntando-lhe: "Que diabos - é o que eu quero saber agora - o senhor estava supondo?".

${ }^{10}$ Aristóteles, Horácio, Longino, A poética clássica, São Paulo, Cultrix, 1988, p. 47-8.
} 
para os delegados, naturalmente), e a duplicidade, a repetição - cujo grande símbolo é o espelho, mas que decerto tem um paralelo na reprodução mecânica da era industrial - estabelece-se com toda sua carga fantasmagórica. São os fantasmas do Império do salão de Madame de Vionnet, mas é também o próprio Strether, que no início vimos a carregar o fardo da "dupla consciência" e que agora também se desdobra com a surpresa de ter contemplado o que ele não podia senão ter contemplado - a surpresa alojada no quadro que ele criou.

"O pequeno fenômeno foi súbito e rápido, tão rápido que por um breve instante a percepção de Strether sobre o incidente distinguiu-se do agudo sobressalto que teve." O leitor é posto assim diante de dois Strethers: o da percepção ou dos sentidos (sense) e o do sobressalto ou comoção (start). O sentido do herói se separa do assombro porque esse assombro evidencia justamente aquilo que o sentido, em primeira instância, não percebeu. Há como que duas instâncias, portanto, de compreensão: uma perfeitamente alheada e outra que, sobressaltada, intui a verdade sobre os fantasmas que rondam as premissas e as paisagens; não são de maneira nenhuma figuras retóricas, mas instâncias bastante concretas, projeções muito reais do seu estado falseado. Como os guerreiros de Nietzsche, uma parte do herói está presa à batalha retratada na tela, mas a outra, diante da inverossimilhança da situação, do falso do falso, é súbito arremessada através o espelho, descobrindo o real - o real tão semelhante ao outro, mas "impossível" como havia advertido Miss Gostrey; o real da insubstancialidade crônica derivada de sua ligação com Mrs. Newsome, o maior dos fantasmas de todos no romance, ostensivamente in absentia; o real, enfim, de sua consciência ludibriada, do engano a que se sujeitou em nome da vida dos ricos. Daí o choque.

E tudo isso ocorrendo na arena, sim, da mente, mas não propriamente da cognição; da contemplação, da sensação e do pressentimento, mas não do pensamento. Quando imagina Maria perguntando-lhe o que estivera supondo, Strether percebe que estivera o tempo "tentando não supor coisa nenhuma". Ele procurou manter o pensamento em suspenso; um trabalho inútil. Porque, bem no fim do episódio, se pega supondo "inumeráveis maravilhas" (innumerable and wonderful things). Ou seja, quando a personagem finalmente procura deduzir algo é para privilegiar a fantasia, a curiosidade, o estado de perplexidade ou de surpresa que se alia à ideia de "wonderful things". A sua suposição equivale, portanto, à visão que se descortina não diante dele, mas em sua mente, das coisas admiráveis que podem ter ocorrido, que estejam ocorrendo e que porventura ainda possam ocorrer. O seu estado de deslocamento estupeficante da realidade (bem como sua aventura que o leva até ali: a sua descoberta da verdade!) guarda um quê do deslumbramento onírico de Alice in Wonderland; curiosamente Strether também se entrega em certo momento a um sono na relva.

E o que sobra da realidade retratada, do quadro da natureza retratada dessa única escapada bucólica da personagem em todo o romance? ${ }^{11}$ Como esse se mostra

${ }^{11}$ Seria um "risco" semelhante ao que se dá com o uso do monólogo interior, segundo Sartre: "A realidade mostrada sem intermediário ao leitor não é mais a própria coisa, seja árvore ou cinzeiro, 
com efeito distante dos quadros pintados por Balzac, das descrições de Flaubert, mesmo aquelas que se tingem com o sangue da Revolução de 1848! Descobrimos nos dois autores uma paisagem objetiva, autônoma, separada da consciência das personagens. Mesmo depois da primeira frase, mais retórica, por exemplo, com que Flaubert inicia a exposição dos Comícios, em Madame Bovary, o leitor é capaz de contemplar a fachada ornada de hera da prefeitura, a bombarda destinada a anunciar a chegada do prefeito e dos agricultores premiados, o colarinho mais alto do que o habitual do uniforme de Binet:

Chegaram, com efeito, esses famosos Comícios! Logo na madrugada da solenidade, todos os habitantes conversaram à porta acerca dos preparativos; tinham engrinaldado de heras a fachada da prefeitura; num prado, fora armada uma barraca para o festejo e, no meio da praça, em frente da igreja, uma espécie de bombarda devia indicar a chegada do prefeito e o nome dos lavradores laureados. A Guarda Nacional de Buchy (Yonville não tinha) reunira-se ao Corpo de Bombeiros, de que Binet era capitão. Este trazia, para a solenidade, um colarinho ainda mais alto que de costume e, sumido na túnica, tinha o busto tão empertigado e imóvel, que toda a parte vital da sua pessoa parecia haver descido às pernas, que se erguiam em cadência de marcha de um só movimento. ${ }^{12}$

Mesmo comparado com a descrição campestre das primeiras narrativas de James, o quadro dos Embaixadores é diferente. Por certo o americano já mostrava apreciação pelas referências literárias. Quando o narrador de "Um peregrino apaixonado", por exemplo, diz que se sente "como um dos andarilhos de Smollett" ao caminhar até Worcester ou que a cidade aonde chega provavelmente foi cenário para onde "as heroínas de Miss Austen, em carruagens e cabriolés", devem ter ido adquirir "boás de pluma de cisne e luvinhas de renda". Mesmo assim, a torre da catedral que em seguida avistamos nos parece bastante real, transfigurada pela luz da tarde. Antes, na sua caminhada, tudo é descrito de maneira bem objetiva: o céu inglês com suas nuvens que passam e se acumulam (em contraste com o azul ininterrupto do firmamento norte-americano), sendo capaz de produzir tempestades repentinas; as pastagens e as encostas íngremes do campo que levam até a vila rural

que nos aliciava de seu sítio, no meio da campina. Bem próximo, admito, a estrada de ferro irrompe feroz de seu túnel de colinas; contudo, naquela charmosa aldeola estão incubadas uma quietude e uma privacidade de antanho, que parecem proibir-nos, tal como se fosse uma violação de confiança, de revelar-lhes o nome remoto. Pegamos uma trilha estreita e verdejante, obscurecida pela altura das sebes; ela levou-nos a uma soberba sede de fazenda, hoje tolhida por sendas e estradas multiplicadas, que restringiram suas antigas prerrogativas senhoriais. ${ }^{13}$

mas a consciência que vê a coisa; o 'real' não é mais que uma representação, mas a representação se torna uma realidade absoluta, pois nos é oferecida como dado imediato". Cf. Jean-Paul Sartre, Que é a literatura? São Paulo, Ática, 2006, p. 123.

${ }^{12}$ Gustave Flaubert, Madame Bovary, São Paulo, Clube do Livro, 1987, p. 148.

${ }^{13}$ Henry James, Um peregrino apaixonado e outras histórias, São Paulo, Planeta, 2005, p. 83-5. 
E por aí segue. Apesar dos comentários literário-afetivos do narrador, tanto antes quanto depois, não resta dúvida de que aquele campo existe como uma entidade desligada de suas considerações. A nós nos parece que, se tivesse havido a possibilidade de passarmos ali um pouco antes, ou um pouco depois da caminhada do narrador com o pobre Searle, encontraríamos aquela paisagem exatamente da forma como foi descrita, ainda tranquilamente rural, embora aqui e ali já se mostrando transformada, como se em meio a uma tensão sutil, pelas marcas crescentes do progresso - as estradas multiplicadas, o trem de ferro etc.

Mas o que dizer do campo de Strether - a despeito de James ter tido o cuidado de povoá-lo com choupos, uma igrejinha de teto inclinado, camponeses com inusitada experiência mundana, uma estalajadeira de tamancos e (para quem alega que as personagens do autor nunca se rebaixam a ponto de entregar-se a uma atividade tão trivial quanto saborear um bom repasto) uma cerveja e até mesmo uma côtelette de veau à l'oseille? São dados bastante objetivos, mas que não constituem uma realidade à parte de Strether, à parte, curiosamente, não de sua visão, mas de sua cegueira. Mais do que à sua memória, mais ainda do que às suas sensações (como seria de esperar num realismo de corte "impressionista"), a paisagem se liga a seus desejos, seus impulsos íntimos necessariamente implicados. Entre o quadro não comprado e o agrément do rio coloca-se essa moldura absurdamente elástica que o autor arma para mostrar um espaço que é a um só tempo concedido à sua personagem e extraído de sua disposição interior. Nos dois casos ligados à ordem particular desse indivíduo no mundo; a primeira como um direito que se dá a um sujeito dominado por essas circunstâncias especiais; a segunda, como as prerrogativas especiais desse sujeito dominado. Nos dois casos, portanto, uma prisão e uma ilusão. No fundo, trata-se de uma natureza supostamente dominada que espelha o estado de dominação do sujeito que julga exercer um domínio sobre ela e depois percebe que nem mesmo esse frágil controle logrou obter. Porque o que o pobre Strether descobre é que sequer consegue dominar as próprias ilusões.

Pensando na dicotomia jamesiana do showing x telling, podemos perguntarnos o que de fato está sendo mostrado. E o que está sendo narrado? À primeira vista temos uma espécie de telling, de relato, pois o autor parece contar o que se passa com o herói; trata-se de um grande panorama bucólico. A cena, o flagrante, a reação dos personagens, tudo isso viria em seguida. Ainda seguindo os termos de James, o quadro campestre, o passeio de Strether, seria uma "preparação de cena" para a "cena" que breve se daria. ${ }^{14}$ No entanto, não nos parece que estejamos aqui diante de um telling puro. A preparação da cena já constitui uma cena, na medida em que a moldura que a envolve já está colocada desde o início - e a

${ }^{14}$ E que, no entanto, não se dá, não exatamente. A cena seria o encontro entre Strether e o casal de namorados. Contudo, no final do capítulo, presenciamos apenas a surpresa deste diante da presença daqueles (e, sugere-se, daqueles diante deste); no seguinte, só vemos Strether, Chad e Madame de Vionnet comentado o evento e traçando planos para o regresso. O momento climático, em si, como ocorre com frequência no método cênico de James, é suprimido em favor de uma visão mais nuançada, posterior, mental: uma cena, portanto, da mente em funcionamento, ruminando os acontecimentos. 
moldura é a mente da personagem. O autor sem dúvida mostra uma paisagem conforme ela se reflete na mente do herói e, na medida em que nos exibe esse quadro refletido como que nos diz através desses reflexos uma série de coisas, e uma das não menos evidentes é que entre o que se mostra e o que o leitor vê há um mundo de inferências ocultas, de não ditos, impulsos reprimidos, constrangimentos políticos e econômicos. Algo não muito distante, nesse sentido, do quadro cediço de muitos romances de Machado que, pelo menos em determinado momento, se não se declarou claramente favorável ao showing, decerto criticou publicamente o telling.

Foi na resenha a $O$ culto do dever, de Macedo. Machado reclama que o leitor não sente o amor de Angelina por Teófilo; o motivo seria que a descrição pálida "não aparece senão na boca do narrador". ${ }^{15}$ Se o leitor não sente é porque o sentimento não lhe foi transmitido e, se não foi transmitido, é porque só conhecemos a história pelo que nos conta o narrador, o telling. Subjaz à crítica a ideia de que há uma espécie de preguiça nesse relato atropelado, nesse dizer sem mostrar, sem convencer, que não logra falar ao coração do leitor. Diferente da narrativa de Iracema; e, para prová-lo, Machado aponta justamente uma cena entre a "selvagem cearense", adornada de flores de maniva, e Martim. Na cena e no diálogo, "vê-se a beleza deste movimento, diante de uma filha da floresta". Vê-se porque a cena mostra. Machado elogia os meios "simples, naturais, e belos" com que Alencar estabelece o quadro. São poucas as personagens, outrossim, que compõem "este drama da solidão, mas os sentimentos que as movem, a ação que se desenvolve entre elas, é cheia de vida, de interesse, e de verdade". ${ }^{16}$

Drama, sentimentos que movem as personagens, o movimento que o leitor "vê" (porque é mostrado): Machado parece fazer aqui uma defesa tão contundente quanto a de James sobre as vantagens do método dramático. Na realidade, se formos analisar o Memorial, e mesmo a maior parte dos romances de maturidade, $\mathrm{e}$ ainda os anteriores, notaremos uma grande quantidade de cenas, muitas vezes em sequência, com o mínimo de descrição. Apesar das intromissões do narrador em primeira pessoa (quando ele existe), o mundo exterior é retratado de forma econômica. "Desci hoje de Petrópolis. Sábado ao sair a barca da Prainha, dei com o desembargador Campos a bordo..." Machado não se preocupa em falar da cidade serrana, ou da barca na baía de Guanabara: a cena inicia-se de chofre. Ou, adiante: "Vi hoje o Tristão descendo a Rua do Ouvidor com o Aguiar; adivinhei-o pelo retrato. Trazia no vestuário alguma cousa que, apesar de não diferir da moda, cá e lá, lhe põe certo jeito particular e próprio". Não só Machado não vê nenhuma necessidade de pintar a rua do Ouvidor, tão conhecida de parte de seu público-leitor, como, o que é mais peculiar, não nos dá nenhuma imagem precisa sobre o que Tristão trajava: era coisa da moda, se bem que diferente, pessoal. E isso basta. ${ }^{17}$

\footnotetext{
15 J. M. Machado de Assis, Obra completa, Rio de Janeiro, Nova Aguilar, 2004, v. 3, p. 845.

${ }^{16}$ Idem, ibidem, p. 851, grifo nosso.

${ }^{17}$ Idem, ibidem, v. 1, p. 1106 e 1133.
} 
96 Literatura e Sociedade

Outras vezes Machado descreve as pessoas da cena, como na missa ao barão de Santa Pia; mas as pinceladas são parcimoniosas, sucintas, presas à ação. O leitor guarda, quase como pequenos tesouros que aqui e ali se espalham, as instâncias descritivas mais alongadas em seus romances maduros, como a subida de Natividade e Perpétua ao morro do Castelo, no início de Esaú e Jacó, ou a pintura das carruagens no cais Pharoux, no mesmo livro; ou ainda a descrição da penúria em que se encontram Rubião e Quincas Borba quando D. Fernanda e Sofia o encontram, no fim de Quincas Borba.

Sem dúvida há bastante "telling"; o narrador nos conta muita coisa; lembra-se de algo e narra; em meio a um bocado de digressões e também um bocado de referências doutas que tanto desagradaram Augusto Meyer. Em James as intromissões retóricas são bem mais discretas, embora haja, e não com tão pouca frequência quanto às vezes se imagina: "já que falamos daquilo que ele, após o regresso, havia de recordar e interpretar, seria conveniente imediatamente dizer que a verdadeira experiência dessas poucas horas revestiu-se, sob o influxo daquela visão tardia - pois apenas se deitou quando já estava amanhecendo - do aspecto que melhor convém a nosso propósito", "Cumpre-nos acrescentar, porém, sem mais delongas", "acabamos de ver que ele falara a Miss Gostrey". Aliás, Os embaixadores trazem justamente, logo no primeiro parágrafo, uma referência a um "eu" autoral: "O princípio operador que acabei de mencionar" (The principle I have just mentioned as operating). ${ }^{18}$

Em Machado, a descrição do mundo que rodeia as personagens ou o narrador são muitíssimo mais enxutas, sobretudo no Memorial, a ponto de o leitor encontrar dificuldade para achar uma "preparação" de cena que vá além de umas poucas linhas ou mesmo de umas poucas palavras. Uma das maiores está no início do romance, quando o conselheiro espreita Fidélia pela primeira vez.

Fomos ao cemitério. Rita, apesar de alegria do motivo, não pôde reter algumas velhas lágrimas de saudade pelo marido que lá está no jazigo, com meu pai e minha mãe. Ela ainda agora o ama, como no dia em que o perdeu, lá se vão tantos anos. No caixão do defunto, mandou guardar um molho de seus cabelos, então pretos, enquanto os mais deles ficaram a embranquecer cá fora.

Não é feio o nosso jazigo; podia ser um pouco mais simples, - a inscrição e uma cruz, - mas o que está é bem feito. Achei-o novo demais, isso sim, Rita fá-lo lavar todos os meses, e isto impede que envelheça. Ora, eu creio que um velho túmulo dá melhor impressão do ofício, se tem as negruras do tempo, que tudo consome. O contrário parece sempre de véspera.

Rita orou diante dele alguns minutos, enquanto eu circulava os olhos pelas sepulturas próximas. Em quase todas havia a mesma antiga súplica da nossa: "Orai por ele! Orai por ela!" Rita me disse depois, em caminho, que é seu costume atender ao pedido das outras, rezando uma prece por todos os que ali estão. Talvez seja a única. A mana é boa criatura, não menos que alegre.

A impressão que me dava o total do cemitério é a que me deram sempre os outros; tudo ali estava parado. Os gestos das figuras, anjos e outras, eram diversos, mas imóveis. Só alguns pássaros davam sinal de vida, buscando-se entre si e pousando nas ramagens, pipilando ou gorjeando. Os arbustos viviam calados, na verdura e nas flores. ${ }^{19}$

\footnotetext{
${ }^{18}$ H. James, The ambassadors, op. cit., p. 17, 328, 348 e 352.

${ }^{19}$ Machado de Assis, Obra completa. op. cit., v. 3, p. 1097-8.
} 
Em seguida, Aires faz um comentário à irmã acerca da senhora que vira (enquanto circulava os olhos) ao pé de uma sepultura; era Fidélia; e um diálogo se trava entre irmã e irmão. Ao que tudo indica, portanto, estamos diante de uma descrição tradicional, em que o mundo pintado pelo narrador distingue-se perfeitamente dele: temos o campo-santo; o jazigo da família, mantido limpo à revelia da vontade de Aires; as outras sepulturas e a estatuária cemiterial, os pássaros gorjeando etc. Aos detalhes do cenário, como essas aves e as flores, soma-se a lembrança do feixe de cabelos da irmã, deitados ainda pretos ao sepulcro, em oposição à cabeça ora branca da personagem - uma particularidade fúnebre-afetiva de alcance quase naturalista.

É interessante, a propósito, esse pormenor, por diversos motivos - e um deles está no fato de que a observação de Aires permite que entrevejamos algo que não está na superfície dos objetos descritos, mas oculto - simultaneamente preservado e apodrecido, junto com o resto da matéria corrupta, sob a terra. Os fios sepultados de cabelo ficam, dessa forma, paralisados no instante eterno da memória, sempre pretos, enquanto os da irmã continuam a transformar-se e sofrer a ação mais imperativa do fluxo cronológico; ação que faz o túmulo envelhecer e escurecer e obriga Rita a mandar limpá-lo constantemente. A natureza que turva a sepultura e encanece os cabelos também transforma (podemos imaginar) a substância que se guarda fora da vista; no entanto, esta última parece mais infensa (pois submetida ao mecanismo da memória) à transformação. Na verdade, cristaliza-se na mesma extensão sempiterna dos mortos a reclamar a lembrança e a oração dos vivos.

Assim constrói-se uma relação de troca e contaminação constante entre vivos e mortos, entre a realidade à vista e longe da vista, uma relação segunda a qual estes últimos chamam pelos primeiros para conservá-los num tempo aistórico, reificado. Ou antes, na acepção desenvolvida por Robert Penn Warren acerca do espírito da época da Depressão americana, sentido e formulado por Faulkner, essa relação sucede num patamar de "história-como-contemplação", em vez da "história-comoexistência"; da "história-como-ritual" em vez da "história-como-ação". ${ }^{20}$ Com isso, essa realidade visível também sofre com ação do substrato invisível, e igualmente paralisa-se. O quadro descrito é, por conseguinte, quase todo fixo e silencioso, com seus arbustos mudos e figuras estáticas. A exceção são as aves, a lembrar que ali, na camada do visível, há a vida, a aproximação dos seres, a sugestão de que tempo que não parou, mas aparentemente avança e se abre à mudança.

Num estudo recente, Fredric Jameson faz uma série de considerações sobre o tempo do récit, que ele acaba associando ao telling - o contar ou, naturalmente, "recitar". De início o relaciona (como Sartre) ao tempo pretérito, como algo terminado, para depois associá-lo (com Benjamin) à morte, ao irrevocável, àquilo

\footnotetext{
${ }^{20}$ Os termos são history-as-contemplated (em vez de history-as-lived) e history-as-ritual (em vez de history-as-action). Ainda assim, segundo Penn Warren, o desejo de mudança que haveria em alguns, de quererem voltar para essa condição de "imutabilidade", já representa, em si, um tipo de mudança. Em Aires, vemos menos um desejo do que uma nostalgia, uma certeza melancólica de que o regresso não é mais possível. Cf. Robert Penn Warren, "Faulkner: past and future", in Faulkner: a collection of critical essays, New Jersey, Prentice-Hall, 1966, p. 5.
} 
que não pode ser mudado (em oposição à repetição ou retificação da existência ordinária, do cotidiano, por exemplo). Ele enfim associa a ideia de irrevogabilidade à escolha do ato que "marca para sempre e do qual não se pode voltar, o ato que se arrasta como uma bola presa a uma corrente" - que pode ser aproximado à categoria de destino ou sina. Em oposição ao destino estaria o "presente existencial" ou "eterno", cujo correspondente é o item do par jamesiano-lubbockiano: o showing, o mostrar, a instância da cena. Jameson também associa esse presente da consciência ao tempo da impessoalidade, que não examinaremos aqui, embora suas relações com o realismo sejam tão flagrantes quanto complexas. ${ }^{21}$

A nós interessa a correlação que podemos traçar, a partir do quadro machadiano, entre o presente existencial que se abre ao movimento e às mudanças e o pretérito dos mortos, que se liga ao destino, àquilo a que não se pode regressar. Nesse sentido, cremos que nossa posição se aproxima da que Sartre fez em seu estudo de O som e a fúria. Para os heróis do romance de Faulkner, o tempo apareceria "decapitado", "destituído de seu futuro"; isto é, um tempo sem a possibilidade do futuro, que o filósofo associa aos feitos e à liberdade. O tempo decapitado nessa comparação liga-se a Aires e, em parte, a Strether, que no fim também se alia mais ostensivamente a ele. Na derradeira visita que faz a Chad ele se sentiu velho na presença do moço, que o trata como a um ancião, de certo modo recuperando uma impressão anterior e, assim, selando seu compromisso com Madame de Vionnet quando fora visitá-la em seu apartamento. Ele sabia que viria a lembrar-se da sensação que ali tivera, em seu último encontro com aquela senhora, "como se aquilo fosse algo muito, muito velho, a coisa mais velha que jamais tocou". É esse foco no pretérito que também faz que, na cena campestre, seu futuro (o que ele veria em seguida) seja algo que ele já experimentava como seu passado (o que vira na galeria de Boston). ${ }^{22}$

Por outro lado, mais do que um presente voltado para o futuro, os pássaros da cena do cemitério do Memorial se mostram conservados nesse "presente sem tempo" em que estão sempre a procurar-se, a pipilar, a voejar e pousar. Mesmo a ideia do acasalamento e reprodução, contida no "buscando-se entre si", precisa ser vista na perspectiva daquilo que, no presente eterno, existe apenas como potencialidade ou realidade alheia. E, no nível da frase, devemos ainda lembrar que as aves estão ali equiparadas aos arbustos, que também "viviam", apesar de quedos e calados.

\footnotetext{
21 "Quero reafirmar que o presente da consciência é de certa forma impessoal, a consciência é em si impessoal; enquanto é objeto da consciência ou do self constitui o local da identidade pessoal no sentido ordinário. Este self, entretanto, é em si apenas um objeto para a consciência impessoal do presente; e de certa forma todas as identificações pessoais do passado-presente-futuro são em outro sentido distintas do presente impessoal, simples objetos, não importa o quanto inseparáveis sejam dele" (Jameson leu este trabalho no XI Congresso Internacional da Associação Brasileira de Literatura Comparada - Abralic - em julho de 2008. Um livro com as conferências desse encontro está no prelo, pela Hucitec).

${ }^{22}$ Jean-Paul Sartre, "On The sound and the fury: time in the work of Faulkner", in Faulkner: a collection of critical essays, New Jersey, Prentice-Hall, 1966, p. 87-93. H. James, The ambassadors, op. cit., p. 336, 352 e 353.
} 
Percebemos, então, que esse quadro não só "prepara" a cena, como a anuncia e comenta-a, fornecendo outrossim uma introdução aos pares dialéticos mortos $\mathrm{x}$ vivos, pretérito x presente existencial, manutenção x renovação, ritual x ação, que marcam todo o romance. Pois o que temos ali? O aparecimento da personagem que deveria constituir o elo com o mundo dos mortos, com o destino que lhe deveria marcar a existência e, no entanto, viria a assinar o contrato com os vivos, independentemente de quem sejam; de mais a mais, essa personagem é aqui apresentada, em essência, pelo olhar de outras pessoas, comprometidas com a primeira das duas instâncias.

A realidade descrita pelo conselheiro é a do que foi e, mais do que foi, manifesta-se dentro do espaço da recordação: não pode ser alterado; paralisou-se em seu caráter imutável, sujeito apenas à saudade e à lágrima, um mundo que precisa de uma boa alma para que, orado, seja assim preservado como história já contada, um tempo sem chance de vida. Trata-se de um mundo tão estranho que nem mesmo as mudanças políticas, como a instauração da República, parecem afetá-lo. Se a República representa a manutenção da oligarquia e o conselheiro é delegado dessa mesma oligarquia, não deixa de constituir uma mudança, posto que modesta, de troca de tabuletas e debêntures de ficção, que ele mesmo assim não sente como sua. Como não sente envolvido pela abolição, por mais que aplauda o fim da escravatura (por razões bem menos sociais do que de brio patriótico), pois o seu mundo é o do Império, da oligarquia escravocrata, da elite colonial.

O romance se passa justamente entre 1888 e 1889, de alguma e significativa mudança no plano político e social brasileiro, e ainda que a mostre apenas em parte, ela não parece abalar sobremaneira o pequeno grupo, o pequeno retrato descrito, pois essa é a gente que selou o compromisso com a paralisia e o sepulcro. Aires faz questão de mostrar o belo exemplo da mana para, quando for contar o mau exemplo de Fidélia, sua suposta traição possa parecer ainda mais cruel. Fidélia e Tristão são esses pássaros, indiferentes aos mortos, buscando-se sobre os despojos de gente a quem nada devem. Cantam e movimentam-se com o despudor alegre, com a fria negligência, com a quase insolência, de seres que parecem estar lá para mostrar que todo esse ritual, todas as preces, súplicas e lágrimas são tão inúteis quanto desprovidas de sentido. Ainda assim, e contra a acusação implícita de Aires, o movimento do geral do romance mostra que, se há uma distinção entre o grupo de Aires e a escolha de Fidélia, essa ação é tão sepulcral quanto a das aves do cemitério. No fundo, não se faz por avanço, mas por oposição; e a obra de Fidélia não leva o casal ao engajamento, mas à fuga; a Portugal, não ao Brasil.

De certa forma, os motivos do romance inteiro, muito sutil e plasticamente, se organizam a partir desse breve quadro de contrastes irreconciliáveis - um quadro que só o conselheiro poderia pintar, sob esse ponto de vista. Portanto, assim como a moldura do quadro natural que envolve a aventura campestre de Strether, o mundo esboçado pelo conselheiro não é, de fato, alheio a ele; é ele mesmo, é a sua vida, é o processo que está prestes a narrar, o seu julgamento sobre as coisas, e o desenlace que, para ele, vinha tão irrevogável quanto a consciência que chega tão tardiamente ao americano iludido. Ademais, devemos reparar que o quadro descrito por Aires corresponde à ideia geral que a personagem fazia de uma realidade 
como aquela; aquele cemitério era como os outros (que havia visto ou conhecido). Sua impressão é pré-moldada, assim como a impressão do campo francês, para Strether, derivou de experiências anteriores.

A diferença reside, com efeito, na forma como o quadro é construído, da perspectiva de uma consciência iludida à ilusão promovida por uma consciência necessariamente perspéctica. E nesses autores inferidos; o de James, mais evidente a despeito de certa medida de encobrimento, mais claro justamente pela luz que é obrigado a lançar aqui e ali em meio à cegueira de seu personagem; e o de Machado, mais indistinto por misturar-se na perspectiva do narrador; nítido apenas quando se percebe o movimento narrativo como um todo. ${ }^{23}$

Em suas obras, tanto James quanto Machado revelam o mundo pela perspectiva de determinados sujeitos mergulhados em historicidade e enfeixados por sua experiência específica e lugar social. Ou seja, o quadro do mundo objetivo é comandado por esse olhar, expondo-se às suas leis, a alguma medida de manipulação ou distorção, e sempre a um necessário estreitamento ou obnubilação, que insinua que o controle das sensações, da percepção ou dos afetos não corresponde ao que a vida pode oferecer de realidade, mas à realidade tal como um ser humano pode perceber num determinado lugar, num determinado tempo - uma porção mais próxima do que entendemos na prática como o real, embora esse também venha, como ocorre na prática, marcado pela ambiguidade.

Nesse movimento ambivalente se pode conciliar outrossim o pretérito da recordação e o presente da consciência. Este último, decerto, também se liga ao devir cronológico das coisas que o sujeito procura apreender, com alguma falha e dificuldade, pois, enquanto o primeiro lhe oferece uma (ilusão de?) significação, o segundo lhe acena com um sentido à custa da própria significação à qual procurava aferrar-se. Se o significado de algo marcado pelo destino parece evidente (digamos, o compromisso com os mortos), ele perde a clareza ou abre-se a diversas possibilidades de sentido quando se recolhe a um tempo quer seja atemporal, quer seja voltado para um devir em estado de potência. Não estamos falando de um tipo de realismo psicológico, pois o contraponto da arte praticada por nossos dois romancistas se estabelece, com maior correção, com a objetividade preconizada por um realismo mais colado à escola (que censurava o subjetivismo do romantismo ou o idealismo anterior). Estamos, sim, falando de um realismo subjetivo, que não se opõe também, necessariamente, a um ideal sempre inalcançável de objetividade ou impassibilité autoral, mas sim à ideia de que o mundo descrito no romance poderia ser visto como algo objetivo, absolutamente desvinculado do

\footnotetext{
${ }^{23}$ O que, aliás, corresponde à ideia de Booth, de que perceberíamos esse "segundo self" autoral num nível significativo bem mais amplo. "Nosso entendimento do autor implícito não inclui apenas significados extraíveis, mas também o conteúdo moral e emocional de cada pedaço de ação e de sofrimento de todos os personagens. Inclui, em suma, a apreensão intuitiva de uma totalidade artística acabada; o valor principal com o qual este autor implícito está comprometido, independentemente de que partido seu criador toma na vida real, é aquele expresso pela forma total". Cf. Booth, The rhetoric of fiction, op. cit., p. 73-4; grifo nosso.
} 
sujeito que o transforma. ${ }^{24}$ Num realismo de tipo subjetivo, consequentemente, não só a vida vincula-se à porção de vida íntima retratada, como, por causa disso, a presença dos dois tempos é sempre possível, ainda que numa síntese problemática, equívoca.

No Memorial o caso se revela na afirmação à Eclesiastes de Aires sobre o "tempo que tudo consome". Em primeiro lugar, o comentário parece vinculado à personagem, que se liga ao passado. Em segundo, refere-se às negruras do tempo, ao ofício que o tempo tem de envelhecer as coisas, de corrompê-las, de leválas à campa e mantê-las lá. No entanto, o "ofício" do tempo é também algo que ele está sempre a realizar, como o pássaro a gorjear. O tempo "sempre" consome; como, por outro lado, também sempre provoca a geração. O tempo, caso pudéssemos pensar nele como sujeito ou consciência, estaria eternamente preso a esses atos de consumir e de gerar. E esse tempo-sujeito é o tempo de Aires, um presente de seu pensamento vislumbrado através das páginas de seu diário. E isso só é possível porque, no romance, o equilíbrio se dá por meio da consciência pensante de Aires.

É claro que há uma diferença, já apontada, entre o presente da consciência expresso nos Embaixadores e o do Memorial. No primeiro, James de fato representa esse funcionamento imediato, dramatizado, da mente, enquanto, no segundo livro, por mimetizar a condição de diário, haveria algum espaço para manipulação - ou seja, haveria um tempo interpondo-se entre o ato e a escrita, mesmo que mínimo. Contudo, o que estamos examinando não é o tempo do que ocorreu, mas o tempo da consciência de Aires reagindo ao sucedido; a sua consciência conforme ela se desenrola nos diários. A manipulação e limitações de Aires entrariam no cômputo da mesma forma que a confusão ou aturdimento de Strether. Para essa consciência, inclusive, a morte (como tudo mais) só pode existir como uma abstração. No entanto, voltando ao caso do Memorial, pois o exemplo ali é mais forte, a morte faz, sim, parte do significado geral como coisa que se aloja não só sob a campa - os cabelos negros de Rita aí preservados -, mas também sobre ela: no negrume da corrupção que é o efeito visível da morte sobre as coisas vivas. A variação cromática que se estabelece entre a morte aliada ao traço da imutabilidade (a cor preta dos cabelos) e a morte como efeito da transformação temporal sobre o que está visível (que pode ser preto sobre o túmulo, mas branco nos cabelos), reveste-se no relato de Aires de uma tensão que o aproxima de uma curiosa comédia de erros. ${ }^{25}$

\footnotetext{
${ }^{24}$ As associações entre subjetivo e objetivo são naturalmente intricadas, e o leitor só precisa passar os olhos pelo verbete "Subjetivo [Subjective]", das Palavras-chave de Raymond Williams (Palavras-chave (um vocabulário de cultura e sociedade), Rio de Janeiro, Boitempo, 2007, p. 386-91), para dar-se conta do fato. Para nós, contudo, basta aqui a simples reação, ainda que nela se pese a influência da filosofia clássica e da escolástica (associando sujeito à mente ou ao sujeito pensante), contida na ideia de subjetivo contra a pressuposição da ciência positivista de que haveria uma maneira absolutamente imparcial ou neutra de aproximar-se do objeto da cognição.

${ }^{25}$ Seguindo o raciocínio de Jameson, a instância pretérita relaciona-se com o regime do récit, ou do destino, enquanto a outra lhe é exterior. No entanto, essa segunda instância não corresponderia
} 
Curiosamente, com isso, nesse momento de máxima contradição, o realismo também pode efetivar-se mediante sua máxima afirmação, porque se revela mais próximo da experiência cotidiana em que cada leitor poderia enxergar-se. E não só porque, como dizia Sartre, a pintura imparcial da sociedade e da condição humana é um "sonho impossível", mas por causa da capacidade do romance de capturar algo que corresponderia à ambiguidade moral da vida. ${ }^{26}$ Ao observar que Lionel Trilling elogia, em vez de criticar, a ambivalência final de Lolita, Booth deduz que, se nossa vida "é moralmente ambígua" e se o livro reforça essa característica, então nos deixa ainda "mais desconcertados do que antes - e, por conseguinte, sua própria falta de clareza constitui uma virtude". ${ }^{27}$ Ou seja, uma boa parcela do público (os que não acreditam na versão "oficial" do retrato isento do mundo) não se importaria com certa medida de equivocidade, com as lacunas e as pontas soltas, o final aberto, pois assim lhe parece que é a própria vida; a vida tal como a percebe a partir de um determinado contexto.

Ora, nesse sentido, a ponte com o leitor fornece como que o último fator da equação que os aproxima da sensibilidade moderna. Cada qual posicionou os seus instrumentos de reflexão a seu modo - por meio de um narrador não confiável ou com grande medida de intromissão autoral, no caso de Machado; ou através de histórias contadas em primeira ou terceira pessoas, "por um refletor profundamente confuso, basicamente iludido e até mesmo obstinado e pernicioso", como se dá em James. ${ }^{28}$ Aires é o típico narrador manipulador, ao passo que Strether, em sua autoilusão, apresenta o olhar toldado pelos mais diversos equívocos. Cada autor também lança mão de determinado procedimento retórico; vimos que ambos o empregam de um jeito ou de outro; nem Aires nem Strether existem sem Machado e James implícitos. No entanto, com qualquer uma destas estratégias, exige-se a participação ativa do leitor inteligente (como pedia o americano com algum ceticismo); somente o leitor pode reconstituir o sentido que, como na vida, funda-se na intrincada relação forjada entre uma determinada consciência e o mundo que a cerca.

Booth argumenta que muitas vezes a ambiguidade derivada da forma engendrada pode gerar disputas insolúveis como a questão da ambivalência de A volta do parafuso, com a preceptora podendo ser tanto a heroína tentando desesperadamente salvar as crianças sob sua tutela quanto o algoz que as leva à loucura e à morte - e, no terreno brasileiro, podemos pensar no caso clássico de Capitu. Mas

ao presente eterno da consciência, mas à forma como esta consciência percebe o devir, e também o passado-presente-futuro, nas coisas que a cercam (por isso, voltando ao nosso raciocínio, a consciência no fundo não tem como compreender a morte; ela está ontologicamente situada noutro plano). Surge aí o mecanismo da percepção ou das sensações por meio do afeto, e Jameson mostra como o afeto entraria na cena, literalmente a cena dramática tal como James a imaginou, a partir do realismo do século XIX, impedindo-a de cair na impessoalidade do presente eterno. Cf. Jameson, op. cit., no prelo.

\footnotetext{
26 J.-P. Sartre, Que é a literatura? op. cit., p. 21.

${ }^{27}$ Booth, The rhetoric of fiction, op. cit., p. 372.

${ }^{28}$ Idem, ibidem, p. 340.
} 
o fato é que - e isso é ainda mais interessante - a questão não surgiu na época de James e de Machado. E, se nenhum dos dois deixou nenhum documento mostrando que pretendiam causar hesitação, ${ }^{29}$ também não deixa de ser verdade que é para suas obras que nos voltamos quando queremos detectar, em seu movimento geral, os sinais da ambiguidade.

Os traços da ambiguidade, bem como os da dúvida, da incerteza e da indeterminação decerto se relacionam com o panorama da modernidade; sua origem mais evidente é a crise da representação do século XIX e seu motor histórico mais poderoso delineia-se em torno das consequências das malfadadas jornadas de junho de 1848. A repercussão pode ser sentida em autores europeus como Baudelaire, Flaubert e Heine, além de órgãos da burguesia como a Revue des Deux Mondes. Os ecos e as consequências artísticas desse fenômeno cruzaram o Atlântico, onde outros fatores certamente se fizeram sentir. São movimentos para os quais a atenção do analista também deveria estar voltada, se os objetivos bem mais modestos deste artigo não o impedissem de buscá-los. ${ }^{30}$

Os leitores da época de James e de Machado, na realidade, não perceberam uma profundidade maior; o estilo tardio, complexo e multifacetado do americano afastou grande parte de seu público, ao passo que o do brasileiro arrancou elogios da crítica nacional. Mas poucos representantes dessa primeira plateia observaram algo além desse nível superficial, porque a ficção de Machado e de James estava fadada, muito mais, a repercutir com um público que já houvesse burilado sua experiência por meio de leituras de Proust, de James Joyce, de Virginia Woolf, de Kafka; para não mencionar Bergson ou Freud. Só esse público poderia desconfiar do que se diz, examinar o que não se diz e ler a narrativa a contrapelo. O mecanismo da memória no estabelecimento do tempo, a dúvida e a alegoria, a hipertrofia do estilo e o apagamento do sujeito como identidade pessoal; depois disso, estávamos prontos para ler Machado e James; com os olhos que eles já nos haviam projetado desde então.

\footnotetext{
${ }^{29}$ A não ser que imaginemos que as amusettes insolúveis como A volta... sirvam a esse propósito.

${ }^{30}$ Sobre esses pontos o capítulo 7 e a terceira parte do livro Realidade possível (veja nota 1) talvez lancem alguma luz.
} 